\title{
Contemporary Issues in Indian Higher Education
}

\section{G. Thirumoorthy}

Assistant Professor (Guest), Department of Education, Bharathiar University, Coimbatore, India

Corresponding author: gisthirumoorthy@gmail.com

Received: 14 Sept., 2020

Revised: 20 Nov., 2020

Accepted: 04 Dec., 2020

\begin{abstract}
According to a United Nations report (2014) with 356 million 10-24 year-olds, India has the world's largest youth population and China is second with 269 million young people, followed by Indonesia (67 million), the US ( 65 million), and Pakistan (59 million). The United Nations Department of Economics and Social Affairs (2019) Central and Southern Asia was home to the largest number of youth (361 million), followed by Eastern and South-Eastern Asia (307 million). It is revealed that the Asian continent is the only region that shares the world-heist youth population. It is fortunate and provides good hops that can utilize the youth power for economic development by converting as skilled human resources by providing higher education. But, unfortunately, the contemporary unhealthy issues in higher education, most of the Asian region failed to effectively utilize the enormous youth power. Especially, India is one of the inevitable countries in the Asian region but it is the $78^{\text {th }}$ place in corrupt nations out of 175 countries which affects higher education also. Keeping as background this article reveals various issues in higher education in India.
\end{abstract}

Keywords: Issues, Education, United Nations, Asian region, youth power

According to a UN report (2019), India is set to become the world's youngest with $64 \%$ of its population in the working-age group. By 2020, the average age of the country will be 29 . The youth population will become the greatest human resource while providing education. Without proper education, the youth population will not able to convert into a productive population. Especially higher education is very essential. Because, higher education alone leads to invention, creativity and ultimately the productivity will be increased. But, the contemporary evidence reveals that higher education in India is not growing positively. Gross Enrolment Ratio (GER) in Higher education in India is $25.8 \%$, which is calculated

How to cite this article: Thirumoorthy, G. (2020). Contemporary Issues in Indian Higher Education. Learning Community, 11(2): 71-77. 
for the 18-23 years of age group (AISHE, 2018) but the students were enrolled in Ph.D. that is less than $0.5 \%$ of the total student enrolment. And the new Annual Employability Survey (2019) reveals that $80 \%$ of Indian engineers are not fit for any job. Further, according to India Skills Report (2019), only $47.38 \%$ of graduates in India are employable. All the above-revealed issues are due to various problems that prevail in the Indian educational field as follows.

\section{Bribe in Recruitment}

According to Yun (2016), the notion of corruption has quite negative connotations worldwide. Corruption in education is said to have the most damaging consequences due to its long-term effect. Corruption in Indian society has prevailed from time immemorial in one form or the other. In today's scenario, if a person wants a government job he has to pay lakhs of rupees to the higher officials irrespective of satisfying all the eligibility criteria (Joubert, 2021). Maheshwari (2019) stated that corruption is frequently found in recruitment, transfers, posting, promotion, etc. In India, many times recruitment, appointment from higher-level Vice-chancellor to Assistant professor are not based on the performance but bribe, family links, allegiance with political parties, religion, caste play a major role. Especially the administrative corruption such as admissions, procurement, leadership influence, recruitment, promotions/appointment, and Academic corruption such as academic dishonesty, cheating, leaking exam questions, favoritism, etc.

\section{Political Influence in Higher Education}

The politician who is in ruling and opposition parties are influencing in the higher education in the form of recommendation in recruitments, forcing to selection and promotion, article publication, promotion, fixing of the expert committee, etc. Beyond these, the political parties are influences in students, teaching and non-teaching academic committees, council, welfare committees, etc. The UNESCO's (2020) International Institute of Educational Planning study on corruption in education released recently says that $25 \%$ of teacher absenteeism in India is among the highest in the world, second only after Uganda that has a higher rate. The global average of teacher absenteeism is about $20 \%$. Teacher absenteeism does not just affect the quality of education; it is also a huge drain on resources resulting in the wastage of $22.5 \%$ of education funds in India the study said. Politics in teacher appointments, promotion, and transfers is a major reason for teacher absenteeism according to the National University for Education Planning and Administration.

\section{Casteism and Religion}

Caste and Religious prejudice is a sin in India. The scheduled caste was first used in the Government of India Act 1 935. During the freedom struggle, Dr. Ambedkar used Scheduled Caste and also established Scheduled Castes Federation. In the Hindu community the people belonging to the lower cast sometimes they use to convert other religion. They have embraced other religions viz, Christianity, Sikhism, Buddhism. It was felt that in these religions there is no caste system as it is found in Hindu society. 
Sooner or later it was realized that the caste system prevails in other religions too in India. Today they are also known as Dalit Christ, Dalit Sikhs, Dalit Buddhists, etc. (Benjamin (2008). Unfortunately, these kinds of discrimination are prevailing even in the education field also.

The AISHE (2018-19) survey's findings show that the representation of Muslims, Scheduled Castes, Scheduled Tribe, and Other Backward Classes in higher education teaching jobs is way below the proportion of their population even after 68 years of independence. Here the Scheduled Cast students constitute $14.9 \%$ and Scheduled Tribes students $5.5 \%$ of the total enrolment. 36.3\% of students belong to Other Backward Classes. 5.2\% of students belong to Muslim Minority and 2.3\% from other Minority Communities. There are many actors are influencing such as sociological, economic, and psychological challenges that are determined for low enrolment of Dalit's, Tribes, and Other Backward Classes in higher education.

Further, the contemporary environment of higher education is becoming a challenge to socially underprivileged students. A large number of suicides by Dalit-Adivasi students and the pattern of their campus experiences give a sense of how caste is present in insidious but very real ways inside educational spaces. That is why a documentary titled The Death of Merit by Insight Foundation, stated 18 Dalit students committed suicide in the four years from 2007 to 2011. According to a report, there have been up to 11 cases of suicide by students, mostly Dalits, in various institutions in Hyderabad between 2007 and 2013. In north India, besides two cases of suicide by Dalit/Adivasi students at the All Indian Institute of Medical Sciences in Delhi, an additional 14 cases of suicide by Dalit students were reported between January 2007 and April 2011.

\section{Plagiarism}

According to World Economic Forum (2018) China placed first place in publishing articles in the field of science and engineering in a peer-reviewed journal (20.67\%), the United States (16.54\%) is in second place and Indian (5.31\%) comes in third place. However, the quality of research publications is gradually decreased and the percentage of plagiarism is increasing. The findings of Smart \& Gaston (2019) reveals that the Asian editors experienced the highest levels of plagiarized/duplicated content. Further, "Indian academics have contributed 35 percent of all articles published in various kinds of fake journals between 2010 and 2014. The International Consortium of Investigative Journalists has identified over 11,000 fake journals during the five years (2010-2015). The Hindu (2019) Indian academics have contributed 35\% of all articles published in about 11,000 fake journals between 2010 and 2014. Most of these articles were in fake engineering journals, followed by articles in fake journals of biomedicine and social sciences. It is an intellectual theft that is punishable under Copyright Act, 1957. To overcome these issues the UGC (2021) initiated that Plagiarism is accepted in India up to $10 \%$ of the thesis or article or book or any other document, it is punishable only when it passes the minimum acceptable percentage. But, very few Indian educational institutions is initiated to implement the latest plagiarism policy. 


\section{Lack of Collaborative, Local and Need Based Research}

In India, there are 54 central universities, 416 state universities, 125 deemed universities, 361 private universities, 7 Institute under State Legislature Act, and 159 Institutes of National Importance which include IIMs, AIIMS, IITs, IIITs, IISERs, and NITs among others are doing many major projects and minor projects and more than a half-century the Indian higher educational institutions are engaged in research and developmental activities. Even though local peoples' needs and micro-level problems are not yet resolved. The severe problems such as India place in 141 in the world ranking in world precipitate income which is very low precipitate income, India goes below $97^{\text {th }}$ place environment quality index (NUMBEO, 2021), in India the percentage of unemployment is around $6.5 \%$ (2021), etc. Hence, it is a need of the hour to do collaborative, local, and need-based research.

\section{Lack of Innovation Ecosystem}

An "innovation ecosystem" is the term used to describe the various players, stakeholders, and community members that are critical for innovation (Millard, 2018). Innovation ecosystems create an active flow of information and resources for ideas to transform into reality. At present there are many autonomous research institutions are researching different field. But, due to lack of collaboration, interaction, integration, etc., the horizontal, vertical, continuity, etc., in innovation is lacking. Hence, it is not only the ecosystem in innovations that is affecting but also the wastages of money, human energy, time duration, etc. An innovation ecosystem should include universities, government, corporations, startup accelerators, venture capitalists, private investors, foundations, entrepreneurs, mentors, Local, state, and federal entities, and the media in transforming new ideas into reality through access and financial investment.

\section{Lack of Indian Pride of Education}

In 1835, Macaulay's Education Policy was attempted to create a system of education that educates only the upper strata of society through English and insisted that English as an official language. After independence, there were many educational policies are introduced to create the Indian pride of education. However, still struggling to establish an Indian pride in the educational system. But, still the there is a fantasy on the English language and western style of education. There were Indian oldest universities and educational hub such as the first, second, and third Sangam, Taxila or Takshashila University, Mithila University, Telhara University, Sharada Peeth Temple University, Nalanda University, Vallabhi University, Pushpagiri University, Odantapuri University, Vikramshila University, Somapura University, Bikrampur University, Morena Golden Triangle University, Kanthalloor Sala University, Jagaddala University, Nadia University, etc., were the last witness for southeast Asian or Indian pride of education. Hence, need to rebuild the Indian Pride of Education by providing and creating mother tongue-based education. The countries such as China, Japan, Korea, etc., are promoting mother based their pride of education; that is why they can adopt the made-in policy India adopted a westernized detached attached method of education; that is why India adopted made in India policy. Hence, it is the 
need of the hour to create Indian pride in education. In the journey the New Education Policy - 2020 seeks to instill in students a rootedness and pride in India, and its "rich, diverse, ancient and modern culture and knowledge systems and traditions".

\section{Challenges in Assessment}

Assessment bias occurs whenever test items offend or unfairly penalize students for reasons related to students' characteristics, such as their race, gender, ethnicity, religion, or socioeconomic status. In India still, manual evaluation is prevailing at all levels. Cost time duration, Lack of Policy, Lack of Training, Technological Issues, Teachers Assessment Issues, Change in Examination Pattern, Challenge in Grading, biases, and lack of transparency in internal and formative evaluation, weaker relationship between learning objective, learning outcomes, and assessment, etc., are becoming severe threats to assessment in higher education. To overcome all the issues need more incorporation of ICT integrated assessment.

\section{Diversity and Higher Education}

Article one in the Constitution states that India, that is Bharat, shall be a Union of States. India that is Bharat which includes various nationalities which are diversified in all the aspects especially geographical, cultural, economic, level of enrolment in higher education, etc. the uniform pattern of education is not suitable for such huge diversified united nationalities of India. Especially, the common entrance examination is a very worst system for such a diversified union of states. Still, there are huge villages that are suffering without road facilities, electricity, and suffering from very poor amenities. In this crucial physical, social and economic environment implementing a uniform pattern of the educational system is a nonsense approach. Hence, need a regional-based educational system, nationality-based reservation policy, and educational standard. To achieve holistic development the education should bring under the state list.

\section{Summary}

To overcome all of the above issues, need a fair political visionary needs. Because the entire educational policy and other reforms are taking place under the decision of the ruling political party. There are many innovative ideas and creativities are available but the implementation is the major problem, that is because of the corrupted political system. All the problems are start with politics. Hence, it requires the hour that is an education system should be rejuvenated without the influence of biased politics.

\section{REFERENCES}

1. AISHE. 2018. All India Survey on Higher Education. All India Survey on Higher Education (pp. 1-296). New Delhi, New Delhi: Government of India, Ministry of Human Resource, Development Department of Higher Education. Retrieved from https://epsiindia.org/wp-content/uploads/2019/02/AISHE-2017-18.pdf 
2. Benjamin. J. 2008. Dalit and higher education in India. The Indian Journal of Political Science, 69(3): 628-642.

3. Devi, L.L. 2017. Political Instability and Its Influence on Higher Education: A Study of Students' Perceptions in Manipur University. International Journal of Humanities \& Social Science Studies (IJHSSS), 3(5): 300-307.

4. India Skills Report. (n.d.). India Skills Report 2019. Retrieved December 13, 2019, from https://www.collegedekho. com/news/indian-graduate-employability-india-skills-report-15016/.

5. MHRD. 2019. All India survey on Higher Education 2018-19. https://www.education.gov.in/ sites/ upload_files/ $\mathrm{mhrd} /$ files/statistics-new/AISHE\%20Final\%20Report\%202018-19.pdf

6. NUMBEO. 2021. Pollution Index by Country 2021. https://www.numbeo.com/pollution/rankings_by_country.jsp

7. Smart, P. and Gaston, T. 2019. How prevalent are plagiarized submissions? Global survey of editors. Learned Publishing, 32(1): 47-56.

8. Trading Economics. 2019. India Corruption Rank. Retrieved November 24, 2019, from https://tradingeconomics. com/india/corruption-rank.

9. UNESCO. 2020. Corruption and Education. https://unesdoc.unesco.org/ark:/48223/pf0000 190247.

10. United Nations | Department of Economic and Social Affairs | Population Division. (12 Aug 2019). Ten key messages, International Youth Day, 12 August 2019. Ten key messages, International Youth Day, 12 August 2019 (1st ed., Vol. 1, pp. 1-4). UNPopulation.

11. Which country leads the world in publishing scientific research? (2020, January 13). World Economic Forum. https:// www.weforum.org/agenda/2020/01/top-ten-countries-leading-scientific-publications-in-the-world/

12. Yun, A. 2016. Corruption in Uzbek higher education: detrimental impurity for the future. https://etico.iiep.unesco. org/en/resource/corruption-uzbek-higher-education-detrimental-impurity-future

13. Constitution of India/Union and territory. 1948. Wikibooks, Open Books for an Open World. https://en.wikibooks. org/wiki/Constitution_of_India/Union_and_territory\#:\%7E:text=Article $\% 201$,-India $\% 20$ Administrative $\% 20$ Divisions\&text $=$ Article $\% 201 \% 20 \mathrm{in} \% 20$ the $\% 20$ Constitution,described $\% 20 \mathrm{in} \% 20$ the $\% 20$ First $\% 20$ Schedule.

14. Maheshwari, V.K. 1919. Corruption penetration into the Indian education system. Http://Www.Vkmaheshwari. Com/. http://www.vkmaheshwari.com/WP/?p=2837\#: :text =Corruption\%20is\%20frequently\%20found $\% 20$ in,caste $\% 20$ play $\% 20 \mathrm{a} \% 20$ major\%20role

15. Subrahmaniam V. 2011. In Dalit student suicides, the death of merit. https://www. thehindu.com/. https://www. thehindu.com/news/national/In-Dalit-student-suicides-the-death-of-merit/article13881245.ece

16. The Economic Times. 2014. India has world's largest youth population: UN report. The Economic Times. Retrieved from https://economic times.Indiatimes. com/news/politics-and-nation/india-has-worlds-largest-youth-populationun-report/articleshow/45190294.cms

17. Millard, M. 2018. What Is an Innovation Ecosystem and How Are They Essential for Startups?MassChallenge. https://masschallenge.org/article/startup-innovation-ecosystem-explained.

18. Pandey, N. 2019. Plagiarism, data manipulation hurting India's research, govt panel raises alarm. ThePrint. https:// theprint.in/india/education/plagiarism-data-manipulation-hurting-indias-research-govt-panel-raises-alarm/260918/

19. Correspondent, S. 2019. Indian universities get free access to Urkund software. The Hindu. https://www.thehindu. com/news/cities/Delhi/indian-universities-get-free-access-to-urkund-software/article28810881.ece 
20. Anwar, S. 2020. Development of Education during British Period in India. Jagranjosh.Com. https://www. jagranjosh.com/general-knowledge/development-of-education-during-british-period-in-india-14453146011\#:\%7E:text=Lord\%20Macaulay's.

21. UN Education And Employability. (n.d.). Retrieved December 13, 2019, from https://in.one.un .org/un-priorityareas-in-india/education-and-employability/.

22. Wikipedia contributors. (2021b, March 6). List of countries by GDP (nominal) per capita. Wikipedia. https:// en.wikipedia.org/wiki/List_of_countries_by_GDP_(nominal)_per_capita. 
